\title{
Penerapan Inquiry Based Learning untuk Meningkatkan Hasil Belajar Matematika Siswa Kelas VI SD Negeri 2 Tulungrejo Tulungagung
}

\author{
Tutik Rahayu $^{1}$ \\ ${ }^{1}$ SD Negeri 1 Tulungrejo Tulungagung \\ Email: ${ }^{1}$ tutikrahayu@gmail.com
}

$\overline{\text { Tersedia Online di }}$
http://www.jurnal.unublitar.ac.id/
index.php/briliant

Sejarah Artikel

Diterima pada 6 April 2018

Disetuji pada 9 April 2018

Dipublikasikan pada 13 Mei 2018

Hal. 175-183

Kata Kunci:

hasil belajar, matematika, inquiry based learning

\section{DOI:}

http://dx.doi.org/10.28926/briliant .$v 3 \mathrm{i} 2.172$

\begin{abstract}
Abstrak: Agar dapat meningkatkan Hasil belajar siswa dalam menyelesaikan soal tentang Operasi pecahan desimal serta untuk tercapainya tujuan pembelajaran perlu diadakan perbaikan pembelajaran dengan menerapkan Model Pembelajaran Inquiry Based Learning. Hasil penelitian menunjukkan bahwa penerapan metode Inquiry Based Learning untuk meningkatkan Hasil belajar siswa pada materi Operasi pecahan desimal siswa Kelas VI SD Negeri 2 Tulungrejo Kecamatan Karangrejo Tulungagung mempunyai kriteria keberhasilan baik. Hal ini dibuktikan dengan adanya peningkatan Hasil belajar siswa berdasarkan nilai post test per siklus dengan nilai di atas KKM yaitu persentase pada siklus I 66,7\% dan pada siklus II 90,0\%.
\end{abstract}

Matematika sebagai ilmu dasar memegang peranan yang sangat penting dalam pengembangan sains dan teknologi, karena matematika merupakan sarana berpikir untuk menumbuhkan dan mengembangkan daya nalar, cara berpikir logis, sistematis dan kritis. Peranan matematika ini tidak hanya terasa dalam bidang matematika saja tetapi aplikasinya juga pada bidang- bidang lain.. Keberhasilan pembelajaran Matematika tersebut tergantung pada siswa dalam proses belajar mengajar, sedangkan keberhasilan siswa tidak hanya tergantung pada sarana dan prasarana pendidikan, serta kurikulumnya. Akan tetapi, Guru dalam proses pembelajaran juga dapat mempengaruhi peningkatan prestasi belajar Matematika siswa, salah satunya dengan penggunaan metode pembelajaran yang tepat oleh Guru sesuai dengan materi yang disampaikan.

Bruner (dalam Hudoyo, 1988:56) mengatakan tentang belajar Matematika sebagai berikut: "Belajar Matematika adalah tentang konsep-konsep dan struktur-struktur Matematika yang terdapat dalam materi-materi yang dipelajari serta menjalankan hubungan antara konsep-konsep dan struktur-struktur itu. Lain dari itu peserta didik lebih mudah mengingat Matematika itu, bila yang dipelajari merupakan pola yang terstruktur". Menurut Syaiful Bahri Djamarah (2002: 12) proses belajar mengajar adalah suatu proses yang dilakukan secara sadar dan bertujuan. Tujuan ini yang menjadi arah ke mana proses belajar mengajar tersebut akan di bawa. Proses belajar mengajar akan berhasil jika mampu memberikan perubahan dalam pengetahuan, pemahaman, keterampilan, dan nilai sikap dalam diri siswa. 
Dalam proses pembelajaran di kelas sering timbul masalah yang pada umumnya dialami oleh siswa. Masalah yang dihadapi siswa bersifat unik berbeda satu sama lain. Misalnya masalah dan kesulitan ataupun rendahnya hasil belajar yang dialami siswa pada mata pelajaran Matematika bisa terjadi karena berbagai faktor diantaranya. 1) Keterbatasan kemampuan, keadaan, minat dan motivasi diri siswa itu sendiri. 2) Situasi belajar di sekolah atau kelas dan kurangnya sarana dan prasarana. 3) Materi pelajaran yang kurang relevan dengan kebutuhan siswa. 4) Metode mengajar yang kurang bisa dipahami siswa bahkan kurangnya alat peraga dan alat bantu mengajar.

Apalagi mata pelajaran Matematika menuntut kemampuan Guru untuk bisa membuat siswa mengerti dan memahami tentang materi yang diajarkan dengan tidak hanya membaca buku dan teori saja melainkan harus disertai alat peraga, contoh, praktek, latihan soal, seperti soal bercerita dan sebagainya, agar siswa memiliki pengetahuan, keterampilan dan bahkan sikap ilmiah yang berujung pada pemerolehan prestasi belajar yang maksimal.

Berdasarkan hasil pengamatan dalam proses belajar mengajar dikelas, keadaan sekolah, dan melalui peninjauan bidang akademik dan non akademik, diperoleh hasil bahwa keadaan Sekolah Dasar Negeri 2 Tulungrejo khususnya siswa kelas VI tahun ajaran 2015/2016 dalam pelajaran Matematika belum menunjukkan hasil belajar sesuai dengan KKM yang ditetapkan terutama pada pengerjaan soal cerita yang memuat operasi pecahan desimal. Padahal, ditinjau dari keadaan fisik sekolah, yaitu ruang kelas VI sudah baik dan sesuai sebagai tempat berlangsungnya proses belajar mengajar. Pengamatan pada proses pembelajaran oleh peneliti dapat disimpulkan bahwa pelaksanaan proses belajar mengajar lah yang belum membuat siswa aktif belajar, sehingga kemampuan siswa belum tergali dengan maksimal.

Hasil belajar merupakan bagian terpenting dalam pembelajaran. Nana Sudjana (2009: 3) mendefinisikan hasil belajar siswa pada hakikatnya adalah perubahan tingkah laku sebagai hasil belajar dalam pengertian yang lebih luas mencakup bidang kognitif, afektif, dan psikomotorik. Dimyati dan Mudjiono (2006: 3-4) juga menyebutkan hasil belajar merupakan hasil dari suatu interaksi tindak belajar dan tindak mengajar. Dari sisi guru, tindak mengajar diakhiri dengan proses evaluasi hasil belajar. Dari sisi siswa, hasil belajar merupakan berakhirnya pengajaran dari puncak proses belajar.Pada ulangan harian Matematika dengan soal cerita yang memuat operasi pecahan desimal, di dapat rata-rata nilai sebesar 64,2 dari 30 siswa, padahal Kriteria Ketuntasan Minimalnya (KKM) telah ditentukan nilai sebesar 70 . Dan hanya 12 siswa yang mendapat nilai di atas 70 . Hal ini berarti, hanya $40 \%$ dari siswa yang telah mencapai ketuntasan belajar, dan yang lainnya memiliki prestasi belajar yang rendah.

Berdasarkan hal tersebut, peneliti meminta bantuan kepada teman sejawat untuk meneliti kekurangan dari pembelajaran yang telah dilaksanakan. Dari hasil diskusi dengan teman sejawat ditemukan masalah-masalah dalam proses pembelajaran Matematika yang menyebabkan menurunkan hasil belajar adalah sebagai berikut: 1) Materi kurang dapat dikuasi siswa secara optimal. 2) Siswa belum dapat menyelesaikan soal-soal cerita operasi pecahan desimal, diantaranya mengidentifikasi operasi campuran yang melibatkan pecahan desimal, seperti penjumlahan, pengurangan dan pembagian desimal. 3) Melihat hasil ulangan harian siswa diatas, bisa dilihat jika penggunaan metode pembelajaran 
dalam pembelajaran Matematika pada siswa kelas VI belum sesuai dan membuat siswa terlihat tidak antusias untuk belajar. 4) Pembelajaran dengan metode konvensional yaitu dengan menjelaskan materi dan siswa hanya melakukan perintah mengerjakan soal tanpa penanaman konsep pembelajaran yang kuat ternyata tidak efektif dalam proses peningkatan prestasi belajar siswa.

Setelah melihat hasil analisa di atas dan tukar pendapat dengan teman sejawat, maka untuk memperoleh hasil belajar yang optimal, tidak hanya memerlukan suatu latihan yang terus menerus, tetapi terlebih dahulu siswa harus mengetahui inti dari materi yang dipelajarinya. Berdasarkan konsep yang mereka temukan sendiri di dalam proses pembelajaran, tentu siswa akan lebih bersemangat, dan aktif belajar serta berusaha mencari penyelesaian masalah yang diberikan oleh Gurunya dengan menggunakan kemampuannya sendiri.

Adanya semangat atau motivasi siswa dalam belajar dan konsep yang tertanam dengan baik, diharapkan siswa mampu menyelesaikan setiap tugas yang diberikan dengan prosedur yang benar, sehingga hasil belajar yang diperoleh menjadi lebih baik dari semula serta terjadi peningkatan prestasi belajar siswa.

Oleh karena itu, demi memperbaiki berbagai masalah yang ada, peniliti memerlukan suatu solusi untuk mengatasi hambatan-hambatan yang terjadi. Akhirnya diputuskan dengan menggunakan Inquiry Based Learning dalam pembelajaran Matematika ini. Inquiry Based Learning adalah sebuah metode pembelajaran yang mana kurikulum dan instruksi seharusnya didasarkan pada tugas dan aktivitas berbasis komunitas yang integratif dan melibatkan para pembelajar dalam tindakan-tindakan sosial pragmatis yang membawa manfaat nyata pada duniaa.

Inquiry based learning (IBL) didasari atas pemikiran John Dewey, seorang pakar pendidikan Amerika, yang mengatakan bahwa pembelajaran, perkembangan, dan pertumbuhan seorang manusia akan optimal saat mereka dikonfrontasikan dengan masalah nyata dan substantif untuk dipecahkan. Ia percaya bahwa kurikulum dan instruksi seharusnya didasarkan pada tugas dan aktivitas berbasis komunitas yang integratif dan melibatkan para pembelajar dalam tindakan-tindakan sosial pragmatis yang membawa manfaat nyata pada dunia.

Metode Inquiry based learning merupakan proses pembelajaran dibangun atas pertanyaan-pertanyaan yang diajukan siswa. Di sini para siswa didorong untuk berkolaborasi untuk memecahkan masalah, dan bukannya sekedar menerima instruksi langsung dari gurunya. Tugas guru dalam lingkungan belajar berbasis pertanyaan ini bukanlah untuk menyediakan pengetahuan, namun membantu siswa menjalani proses menemukan sendiri pengetahuan yang mereka cari. Jadi, guru berfungsi sebagai fasilitator dan bukan sumber jawaban. Inquiry Based Learning adalah proses pembelajaran dibangun atas pertanyaan-pertanyaan yang diajukan siswa. Di sini para siswa didorong untuk berkolaborasi untuk memecahkan masalah, dan bukannya sekedar menerima instruksi langsung dari gurunya. Tugas guru dalam lingkungan belajar berbasis pertanyaan ini bukanlah untuk menyediakan pengetahuan, namun membantu siswa menjalani proses menemukan sendiri pengetahuan yang mereka cari. Hal ini bertujuan agar prestasi Prestasi Belajar siswa dapat meningkat. 


\section{METODE}

Dalam pelaksanaan Penelitian Perbaikan Pembelajaran ini yang menjadi subjek adalah seluruh siswa kelas VI Sekolah Dasar Negeri 2 Tulungrejo Kecamatan Karangrejo Kabupaten Tulungagung tahun pelajaran 2015/2016 sebanyak 30 siswa yang terdiri dari 19 siswa putra dan 11 siswa putri. Lokasi yang digunakan tempat penelitian adalah ruang kelas VI Sekolah Dasar Negeri 2 Tulungrejo Kecamatan Karangrejo Kabupaten Tulungagung Tahun Pelajaran 2015/2016. Penelitian dilaksanakan pada semester 2, pada tanggal 12 Januari 2016 sampai dengan 19 Januari 2016.

Berdasarkan variable yang diteliti dan tujuan yang hendak dicapai, mata metode penelitian yang digunakan adalah dengan teknik korelasi. Dengan berbagai metode yang digunakan peneliti, peneliti berupaya untuk meningkatkan hasil belajar Matematika terutama pengerjaan soal cerita yang memuat operasi pecahan desimal siswa kelas VI SD Negeri 2 Tulungrejo Kecamatan Karangrejo Kabupaten Tulungagung dengan menggunakan Inquiry Based Learning.

Hasil pengidentifikasian dan penetapan masalah, peneliti kemudian mengajukan suatu solusi yang berupa penerapan Inquiry Based Learning yang dapat dimanfaatkan Guru untuk digunakan sebagai metode pengajaran dalam pembelajaran Matematika kelas VI SD Negeri III Segawe Kecamatan Pagerwojo Kabupaten Tulungagung. Penelitian ini dilakukan dengan dua siklus, dimana masing-masing siklus dikenai perlakuan yang sejenis dengan bobot yang beda. Dibuat dua siklus dimaksudkan untuk memperbaiki system pengajaran yang dilaksanakan.

Adapaun ragam instrument penelitian tindakan kelas yang telah dipersiapkan yaitu, Rencana Pelaksaaan Pembelajaran sebagai instrument rencana pelaksanaan tindakan. Lembar observasi Guru sebagai instrument utama pengumpul data proses dan lembar observasi siswa, wawancara, angket dan catatan lapangan sebagai instrument pendukung pengumpul data proses. Selain itu juga terdapat instrument pengumpul data hasil, yang dapat dikumpulkan dari prestasi belajar berdasarkan soal-soal yang diberikan, serta ketrampilan siswa berdasarkan rubrik yang ada.

Teknik analisis yang digunakan yaitu deskriptif persentase. Data hasil penelitian yang dianalisis meliputi rata-rata kelas, ketuntasan belajar individu dan ketuntasan belajar secara klasikal. Selanjutnya hasil analisis data diperoleh baik secara kualitatif (dengan kata-kata) dan kuantitatif (dengan grafik). Hasil ini diinterprestasikan dan disimpulkan untuk menjawab permasalahan yang ada.

Analisis data dari sumber-sumber informasi hasil penelitian di dapat dari: 1) Analisis Data Observasi, Data hasil observasi keterlaksanaan pembelajaran melalui Inquiry Based Learning dan observasi aktivitas siswa dianalisis secara deskriptif untuk memberikan gambaran pelaksanaan pembelajaran dengan menggunakan Inquiry Based Learning. 2) Analisis Data Wawancara, Hasil wawancara dengan siswa dianalisi secara deskriptif dengan lembar angket untuk mengetahui pendapat Guru dan siswa terhadap pembelajaran. 3) Analisis Data Tes, Berdasarkan hasil tes siswa, setiap soal diberi skor kemudian diperoleh nilai untuk setiap siswa. 


\section{HASIL}

\section{Pra Tindakan}

Tabel berikut adalah daftar frekuensi nilai ulangan harian Matematika soal cerita yang memuat operasi pecahan desimal siswa kelas VI SD Negeri 2 Tulungrejo Kecamatan Karangrejo Kabupaten Tulungagung, dengan nilai KKM sebesar 70:

Tabel 1 Daftar Nilai Ulangan Harian Kondisi Awal

\begin{tabular}{|l|l|l|}
\hline Nilai & Frekuensi & Prosentase \\
\hline $0-40$ & 0 & $0 \%$ \\
\hline $41-69$ & 18 & $60 \%$ \\
\hline $70-100$ & 12 & $40 \%$ \\
\hline Jumlah & 30 & $100 \%$ \\
\hline
\end{tabular}

Dari tabel diatas dapat kita lihat tidak siswa atau $0 \%$ yang mendapat nilai antara $0-40$, ada 18 siswa atau 60\% yang mendapat nilai antara $41-69$, dan ada 12 siswa atau $40 \%$ yang mendapat nilai antara $70-100$. Dengan ketentuan nilai KKM 70, maka dapat disimpulkan jika pencapaian prestasi nilai $70-100$ yang hanya $40 \%$ merupakan prestasi yang rendah.

Selain itu, dari proses wawancara diperoleh kesimpulan bahwa siswa kurang berminat dalam mengerjakan soal cerita yang memuat operasi pecahan desimal, serta dalam pembelajaran Guru lebih sering menggunakan ceramah sehingga siswa merasa jenuh dan bosan, akibatnya minat siswa untuk belajar Matematika terutama pada operasi pecahan desimal menjadi berkurang sehingga mempengaruhi hasil prestasinya.

\section{Siklus 1}

Pelaksanaan pembelajaran, Guru masih menghadapi berbagai kendala, antara lain: 1) Masih ada kelompok yang bingung dalam mengikuti langkahlangkah yang tertera dalam lembar kegiatan. 2) Masih ada beberapa siswa yang belum aktif dalam pelaksanaan percobaan. 3) Ketika pelaksanaan diskusi, ada beberapa siswa yang tidak aktif menyampaikan pendapatnya. 4) Dalam menyimpulkan hasil percobaan, terdapat 2 (dua) kelompok yang malu untuk presentasi, dan hanya terdapat 3 (tiga) siswa yang mengajukan pertanyaan.

Adapun prosentase hasil observasi dalam pelaksanaan percobaan pada siklus I dapat dilihat dari tabel 3 bawah ini. Perhitungan prosentase keberhasilan siklus I di bawah ini diskusikan juga dengan teman sejawat.

\section{Tabel 2 Prosentase Hasil Observasi Siklus I}

\begin{tabular}{|l|l|l|}
\hline No & Kegiatan Siswa & Prosentase \\
\hline 1 & Kelengkapan menyiapkan alat dan bahan percobaan & $40 \%$ \\
\hline 2 & Keruntutan langkah-langkah dalam pelaksanaan kegiatan percobaan & $48 \%$ \\
\hline 3 & Keaktifan siswa selama melaksanakan kegiatan percobaan & $60 \%$ \\
\hline 4 & Keaktifan siswa dalam mengutarakan pendapat saat berdiskusi & $40 \%$ \\
\hline 5 & Kesimpulan akhir sesuai percobaan & $47 \%$ \\
\hline
\end{tabular}

Hasil post test pada siklus pertama dapat menjadi perhitungan persentase peningkatan prestasi hasil belajar siswa. Dengan acuan penilaian tetap 
berdasarkan nilai KKM yang telah ditetapkan yaitu paling sedikit siswa memperoleh nilai 70. Adapun rekapitulasi hasil test siklus I adalah sebagai berikut:

Tabel 3 Hasil Post Test Siklus Pertama

\begin{tabular}{|l|l|l|}
\hline No & Deskripsi & Nilai \\
\hline 1 & Jumlah Nilai & 2195 \\
\hline 2 & Rata-rata Hasil Post Test & 73,2 \\
\hline 3 & Jumlah siswa yang mendapat nilai diatas KKM (70) & 20 \\
\hline 4 & Presentase siswa yang mendapat nilai diatas KKM (70) & $66,7 \%$ \\
\hline 5 & Jumlah siswa yang mendapat nilai dibawah KKM (70 & 10 \\
\hline 6 & Presentase siswa yang mendapat nilai dibawah KKM (70) & $33,3 \%$ \\
\hline
\end{tabular}

Nilai rata-rata hasil post test, dapat dihitung dari $: \dot{X}=\overline{\Sigma N}$, Jadi $\dot{X}=$ $\frac{2195}{30}=73,2$. Nilai KKM $=70$. Jadi sudah ada peningkatan prestasi belajar, namun hanya sedikit. Rumus Ketuntasan Individu (prestasi belajar siswa) $=$ Esiswa yang mendapat nilai $\geq 70$

$$
\begin{aligned}
& \text { Esiswa } \quad \text { x } 100 \% \text {. Jadi, Ketuntasan Individu (prestasi belajar } \\
& \text { siswa) }=\frac{20}{30} \times 100 \%=66,7 \%
\end{aligned}
$$

Masing kurang dari indicator pencapaian siklus I sebesar $85 \%$ atau lebih. Maka dilanjutkan percobaan pembelajaran dengan Inquiry Based Learning pada siklus II.

Tabel berikut adalah daftar frekuensi nilai post test siklus I Matematika operasi pecahan desimal dengan soal pengerjaan soal cerita siswa kelas VI SD Negeri 2 Tulungrejo Kecamatan Karangrejo Kabupaten Tulungagung setelah pembelajaran menggunakan Inquiry Based Learning, dengan nilai minimal KKM sebesar 70:

Tabel 4 Daftar Nilai Ulangan Harian Siklus I

\begin{tabular}{|l|l|l|}
\hline Nilai & Frekuensi & Prosentase \\
\hline $0-40$ & 0 & $0,00 \%$ \\
\hline $41-69$ & 10 & $33,3 \%$ \\
\hline $70-100$ & 20 & $66,7 \%$ \\
\hline Jumlah & 30 & $100 \%$ \\
\hline
\end{tabular}

Dari tabel diatas dapat kita lihat terdapat 10 siswa atau $33,3 \%$ yang mendapat nilai antara 41 - 69, dan 20 siswa atau $66,7 \%$ yang mendapat nilai antara 70 - 100. Dengan ketentuan nilai KKM 70, dapat disimpulkan jika pencapaian prestasi nilai 70 - 100, maka prestasi belajar siswa telah meningkat dari $40 \%$ menjadi $66,7 \%$. Namun karena belum mencapai target indicator pencapaian siklus I sebesar $85 \%$ atau lebih, maka akan dilanjutkan ke Siklus II.

\section{Siklus II}

Dalam pelaksanaan proses pembelajaran, Guru telah melaksanakan perbaikan dari siklus I, siswa sudah mengalami kemajuan dan pelaksanaan-pun telah berjalan baik. Namun Guru menemukan masalah baru dalam pelaksanaan siklus II, yaitu: 1) Beberapa siswa masih kesulitan mencari brosur diskon untuk 
perhitungan persen dan desimal. Namun diantisipasi oleh peneliti dengan menertibkan siswa. 2) Masih terdapat 3-4 siswa yang malu dalam presentasi dan kurang aktif dalam diskusi kelompok.

Adapun prosentase hasil observasi dalam pelaksanaan percobaan pada siklus II dapat dilihat dari tabel bawah ini. Perhitungan prosentase keberhasilan siklus II di bawah ini diskusikan juga dengan teman sejawat.

Tabel 4.5 Prosentase Hasil Observasi Siklus II

\begin{tabular}{|l|l|l|}
\hline No & Kegiatan Siswa & Prosentase \\
\hline 1 & Kelengkapan menyiapkan alat dan bahan percobaan & $90 \%$ \\
\hline 2 & Keruntutan langkah-langkah dalam pelaksanaan kegiatan percobaan & $85 \%$ \\
\hline 3 & Keaktifan siswa selama melaksanakan kegiatan percobaan & $90 \%$ \\
\hline 4 & Keaktifan siswa dalam mengutarakan pendapat saat berdiskusi & $90 \%$ \\
\hline 5 & Kesimpulan akhir sesuai percobaan & $89 \%$ \\
\hline
\end{tabular}

Hasil post test pada siklus kedua dapat menjadi perhitungan persentase peningkatan prestasi belajar siswa. Dengan acuan penilaian tetap berdasarkan nilai KKM yang telah ditetapkan yaitu paling sedikit siswa memperoleh nilai 70 . Adapun rekapitulasi hasil test siklus II adalah sebagai berikut:

Tabel 6 Hasil Post Test Siklus Kedua

\begin{tabular}{|l|l|l|}
\hline No & Deskripsi & Nilai \\
\hline 1 & Jumlah Nilai & 2495 \\
\hline 2 & Rata-rata Hasil Post Test & 83,2 \\
\hline 3 & Jumlah siswa yang mendapat nilai diatas KKM (70) & 27 \\
\hline 4 & Presentase siswa yang mendapat nilai diatas KKM (70) & $90 \%$ \\
\hline 5 & Jumlah siswa yang mendapat nilai dibawah KKM (70 & 3 \\
\hline 6 & Presentase siswa yang mendapat nilai dibawah KKM (70) & $10 \%$ \\
\hline
\end{tabular}

Nilai rata-rata hasil post test, dapat dihitung dari : $\dot{X}=\overline{\Sigma N}$, Jadi $\dot{X}=$ $\frac{2495}{30}=83,2$. Nilai KKM $=70$. Jadi sudah ada peningkatan prestasi belajar yang signifikan. Rumus Ketuntasan Individu (prestasi belajar siswa) =

Esiswa yang mendapat wilai $\geq 70$

Esiswa $\times 100 \%$. Jadi, Ketuntasan Individu (prestasi belajar siswa) $=\frac{27}{30} \times 100 \%=90 \%$

Telah mencapai indicator pencapaian siklus II sebesar $85 \%$ atau lebih. Maka tidak perlu dilanjutkan percobaan pembelajaran dengan Inquiry Based Learning pada siklus III.

Tabel berikut adalah daftar frekuensi nilai post test siklus II Matematika dengan soal cerita operasi pecahan desimal siswa kelas VI SD Negeri 2 Tulungrejo Kecamatan Karangrejo Kabupaten Tulungagung setelah pembelajaran menggunakan Inquiry Based Learning siklus II, dengan nilai minimal KKM sebesar 70:

Tabel 7 Daftar Nilai Ulangan Harian Siklus II

\begin{tabular}{|c|c|c|}
\hline Nilai & Frekuensi & Prosentase \\
\hline
\end{tabular}

181 BRILIANT: Jurnal Riset dan Konseptual

Volume 3 Nomor 2, Mei 2018 


\begin{tabular}{|l|l|l|}
\hline $0-40$ & 0 & $0,00 \%$ \\
\hline $41-69$ & 3 & $10 \%$ \\
\hline $70-100$ & 27 & $90 \%$ \\
\hline Jumlah & 30 & $100 \%$ \\
\hline
\end{tabular}

Dari tabel diatas dapat kita lihat terdapat 3 siswa atau $10 \%$ yang mendapat nilai antara $41-69$, dan 27 siswa atau $90 \%$ yang mendapat nilai antara 70 - 100. Dengan ketentuan nilai KKM 70, dapat disimpulkan jika pencapaian prestasi nilai 70 - 100, maka prestasi belajar siswa telah meningkat dari $66,7 \%$ menjadi 90\%. Dengan 90\% maka telah tercapai indicator pencapaian siklus II sebesar yang $85 \%$ atau lebih, maka tidak perlu dilanjutkan ke Siklus III.

\section{PEMBAHASAN}

Berdasarkan hasil pelaksanaan pada siklus I, II dapat dinyatakan bahwa terjadi peningkatan kualitas pembelajaran yang tampak dan perolehan hasil evaluasi dan keaktifan siswa.

Dari siklus I, hasil observasi menunjukkan, prosentase keberhasilan kelengkapan menyiapkan alat dan bahan percobaan $40 \%$, prosentase keruntutan langkah-langkah yang ditempuh dalam pelaksanaan percobaan $48 \%$, prosentase keaktifan siswa dalam melaksanakan kegiatan percobaan $60 \%$, prosentase keaktifan siswa dalam mengutarakan pendapat saat berdiskusi $40 \%$ dan prosentase hasil penarikan kesimpulan akhir sesuai percobaan $47 \%$.

Dari siklus II hasil observasi menunjukkan, prosentase keberhasilan metode kelengkapan menyiapkan alat dan bahan percobaan siswa yang disiapkan $90 \%$, prosentase keruntutan langkah-langkah yang ditempuh dalam pelaksanaan percobaan $85 \%$, prosentase keaktifan siswa dalam melaksanakan kegiatan percobaan $90 \%$, prosentase keaktifan siswa dalam mengutarakan pendapat saat berdiskusi $90 \%$ dan prosentase hasil penarikan kesimpulan akhir sesuai percobaan $89 \%$.

Dapat kita lihat adanya prosentase kenaikan nilai Matematika mulai dari kondisi awal pra tindakan, diketahui baru 12 siswa atau $40 \%$ yang mengalami ketuntasan belajar dan mendapatkan nilai sesuai dengan KKM. Hasil evaluasi siklus I menunjukkan baru 20 siswa atau $66,7 \%$ yang mengalami ketuntasan belajar dan mendapat nilai sama dengan atau di atas KKM yaitu 70. Hal itu menunjukkan bahwa pelaksanaan siklus I belum mencapai keberhasilan, karena indicator pencapaian adalah sebesar $85 \%$ atau lebih. Siklus II menunjukkan ada 27 siswa atau 90\% dari 30 siswa yang mengalami ketuntasan belajar. Sehingga peneliti menyimpulkan bahwa pada siklus II ini peneliti telah mencapai keberhasilan dari penelitian tindakan kelas yang telah dilakukan.

Ketika peneliti melaksanakan siklus I, peneliti mengalami berbagai kendala antara lain masih ada siswa yang kesulitan membuat soal cerita yang memuat operasi pecahan desimal. Masih ada kelompok yang bingung dalam mengikuti langkah-langkah yang tertera dalam lembar kegiatan. Masih ada beberapa siswa yang belum aktif dalam pelaksanaan percobaan. Ketika pelaksanaan diskusi, ada beberapa siswa yang tidak aktif menyampaikan pendapatnya. Dalam menyimpulkan hasil percobaan, terdapat 2 (dua) kelompok yang malu untuk presentasi, dan hanya terdapat 3 (tiga) siswa yang mengajukan pertanyaan. 
Peneliti kemudian melaksanakan siklus II sebagai perbaikan siklus I, sebelum pelaksanaan siklus II ini peneliti mengganti rencana pembelajaran Inquiry Based Learning baru yaitu dengan memberikan tugas kepada siswa untuk membawa brosur diskon belanja di majalah, koran atau internet. Dalam pelaksanaan percobaan, peneliti senantiasa memberi bimbingan untuk siswanya dalam melaksanakan langkah-langkah sesuai lembar kegiatan. Peneliti pun memberi bimbingan siswa saat berdiskusi untuk menarik kesimpulan. Dengan adanya motivasi guru berupa reward, siswa telah terlihat aktif dalam kegiatan pembelajaran dalam melaksanakan percobaan, presentasi di depan kelas dan berdiskusi menarik kesimpulan. Meskipun ada kendala yaitu siswa masih kesulitan mencari brosur diskon untuk perhitungan persen dan desimal dan suasana menjadi gaduh, namun dengan hasil prestasi belajar yang dicapai dapat disimpulkan bahwa penelitian tindakan kelas dari siklus II ini telah berhasil.

Berdasarkan hasil observasi dan pelaksanaan siklus I dan II juga dapat kita amati adanya perubahan kenaikan prosentase dalam menyiapkan alat dan bahan, keruntutan langkah-langkah siswa dalam melaksanakan percobaan, keaktifan siswa dalam melaksanakan kegiatan percobaan, keaktifan siswa ketika berdiskusi dan hasil akhir atau simpulan yang diperoleh dari hasil kegiatan diskusi.

\section{KESIMPULAN}

Berdasarkan hasil penelitian tindakan kelas yang telah dilaksanakan dalam 2 siklus dengan menerapkan Inquiry Based Learning dalam pembelajaran Matematika pada siswa kelas VI SD Negeri 2 Tulungrejo Kecamatan Karangrejo Kabupaten Tulungagung, dapat dibuat kesimpulan sebagai berikut : Penerapan Inquiry Based Learning dapat meningkatkan hasil belajar Matematika siswa kelas VI SD Negeri 2 Tulungrejo Kecamatan Karangrejo Kabupaten Tulungagung.

\section{SARAN}

Berdasarkan hasil penelitian, maka ada beberapa saran yang dapat dipergunakan sebagai bahan pertimbangan dan sebagai bahan uraian penutup penelitian tindakan kelas ini, antara lain: 1) Bagi Guru, Hendaknya mempersiapkan secara cermat perangkat pendukung pembelajaran dan fasilitas belajar yang diperlukan, karena sangat mempengaruhi efektivitas dan efisiensi pembelajaran yang pada akhirnya berpengaruh pada proses dan hasil belajar Matematika siswa. 2) Bagi Siswa, Hendaknya ikut berperan aktif dalam proses pembelajaran, selalu mengerjakan tugas-tugas yang diberikan guru dan meningkatkan usaha belajar sehingga dapat memperoleh prestasi yang diharapkan. 3) Bagi Sekolah, Hendaknya mengupayakan pengadaan berbagai media pembelajaran Matematika untuk kelas rendah, baik bantuan maupun swadaya sekolah, sehingga lebih menunjang dalam penanaman konsep-konsep Matematika secara lebih nyata sekaligus meningkatkan aktivitas belajar siswa.

\section{DAFTAR RUJUKAN}

Dimyati., \& Mudjiono. 2006. Belajar dan Pembelajaran. Jakarta: Rineka Cipta. Djamarah, Syaiful Bahri. 2002. Psikologi Belajar. Jakarta : PT. Rineka Cipta Hudoyo, H., 1988. Strategi Belajar Mengajar Matematika. Jakarta: DepDikbud. Sudjana, Nana. 2009. Penilaian Hasil Proses Belajar Mengajar. Bandung: Remaja Rosdakarya. 